\title{
ANTIOXIDANT STUDY OF USNIC ACID AND ITS DERIVATIVE USNIC ACID DIACETATE
}

\author{
R. Ananthi ${ }^{1}$, A. Tinabaye ${ }^{2}$, G. Selvaraj ${ }^{3}$ \\ ${ }^{I}$ Research Scholar, Department of Chemistry, Kanchi Mamunivar Centre for Post Graduate Studies, Lawspet, \\ Puducherry, India \\ ${ }^{2}$ Associate Professor, Department of Chemistry, Kanchi Mamunivar Centre for Post Graduate Studies, Lawspet, \\ Puducherry, India. \\ ${ }^{3}$ Research Scholar, Department of Chemistry, Kanchi Mamunivar Centre for Post Graduate Studies, Lawspet, \\ Puducherry, India
}

\begin{abstract}
Currently interest towards the study of antioxidant efficiency of the lichen metabolites was given prior attention in the field of research. As the free radical accumulation in human cells causes several chronic diseases which can be eliminated with the help of antioxidants. In our present study we have isolated the lichen secondary metabolite Usnic acid from Usnea luridorufa and also prepared the acetyl derivative of Usnic acid. The in vitro antioxidant activity of Usnic acid and Usnic acid diacetate under DPPH free radical scavenging, FRAP, Superoxide dismutase activity, Metal chelating activity, Phosphomolybdenum activity, Hydroxyl scavenging activity, Lipid peroxidation inhibiting activity were studied. The antioxidant potential of the Usnic acid and its derivative Usnic acid diacetate were compared. The $I_{50}$ value are also determined. Both the test compounds possesses significant antioxidant activity under the studies.
\end{abstract}

Keywords: Antioxidant efficiency, Usnic acid, diacetate, Tannic acid.

\section{INTRODUCTION}

Lichens are in mutual relationship with algae and fungi both of them benefits each other by their association, here the fungal partner was responsible for the production of lichen secondary metabolites such as depsides, dibenzofurans, depsidones etc. The lichen secondary metabolites have been used as medicine traditionally, as they possesses antimicrobial, antitumor, antioxidant, anti-inflammatory, wound healing, antiviral, analgesic properties[1]. The frequent generation of free radicals and Reactive Oxygen Species(ROS) in body metabolism causes several degenerative diseases which includes tumor cell growth, inflammation, defects in cardiovascular system, enhances the aging process and triggers the neurological disorders[2,3]. In order to get rid of those ROS the necessity of antioxidants has to be considered but there is insufficiency in the body metabolism to acquire the antioxidants which leads to the search of external antioxidant resource. Many synthetic antioxidants have been used as supplementary to defend against ROS but are associated with several side effects. Searching of natural antioxidant resources have been very essential for the therapeutic supplements. In our present study, the antioxidant efficiency of usnic acid and its diacetyl derivative usnic acid diacetate were analyzed.

\section{EXPERIMENTAL SECTION}

\subsection{Collection and Identification of Lichen Material}

The lichen species Usnea luridorufa stirt. was collected from kodaikanal hills, Dindigul district, Tamil Nadu (altitude: $2268 \mathrm{~m}$ ). This lichen species was authenticated from Botanical Survey of India, Allahabad.

\subsection{Isolation of Usnic Acid from Usnea Luridorufa}

The fresh lichen material was air dried and powdered. A coarsely powdered lichen material $(75 \mathrm{~g})$ was extracted with acetone (2l) under reflux condition for about $6 \mathrm{hr}$. The extract was concentrated under vacuum using a rotatory evaporator which yields $(8 \mathrm{~g})$, a brown residue.

The concentrated extract $(8 \mathrm{~g})$ was fractioned on column chromatography. The benzene fractions yields $100 \mathrm{mg}$ of an yellowish crystalline solid which was found to be single in TLC (solvent system: Toluene : Acetic acid, 170:30). The compound was recrystallized from benzene, an yellow prismatic rods which melts at $202{ }^{\circ} \mathrm{C}$. It gave a reddish brown colour with neutral ferric chloride and with conc. Sulphuric acid gave a deep yellow solution turning orange red on standing. It did not give any colour with bleaching power. The compound obtained was confirmed as Usnic acid (Fig: 1) with the help of Co-TLC with the authentic sample and spectral data. 
<smiles>CC(=O)C1=C(O)C=C2Oc3c(C(C)=O)c(O)c(C)c(O)c3C2(C)C1=O</smiles>

Fig: 1. Usnic acid

\subsection{Preparation of Diacetate Derivative for Usnic}

\section{Acid}

The compound usnic acid $(0.2 \mathrm{~g})$ was suspended in acetic anhydride $(2 \mathrm{ml})$ and a drop perchloric acid $(60 \%)$ was added when the solid went into solution. It was kept undisturbed at room temperature for $2 \mathrm{hr}$ and then poured over crushed ice. The oily mass solidified a pale yellow solid. After keeping overnight, it was filtered and recrystallized from methyl alcohol. The pale yellow needles melts at $201^{\circ} \mathrm{C}$. The compound Usnic acid diacetate (Fig: 2) was confirmed with spectral data.

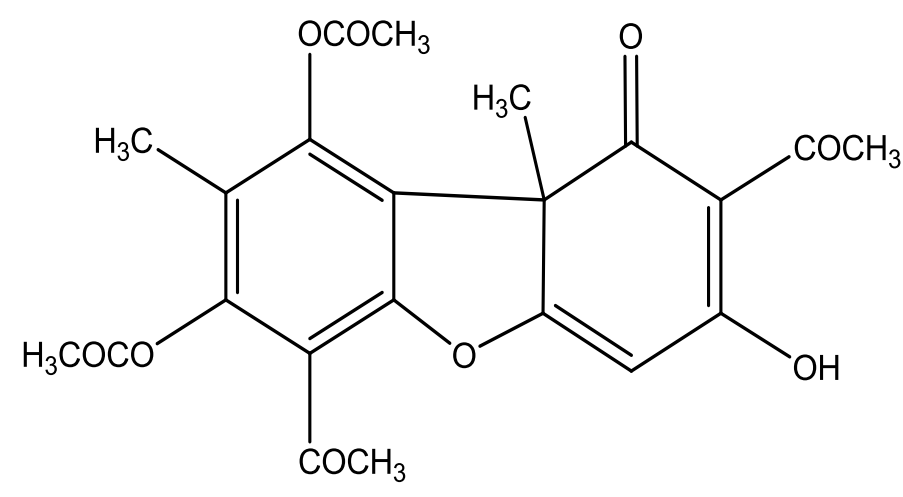

Fig: 2. Usnic acid diacetate

\section{MATERIALS AND METHODS}

\subsection{Free Radical Scavenging Activity by DPPH*}

The DPPH radical scavenging ability of Usnic acid and Usnic acid diacetate were determined based on the hydrogen donating or radical scavenging ability, using the stable radical DPPH, according to the method of Blois (1958)[4]. The test compounds Usnic acid and Usnic acid diacetate were taken at different concentrations (100-500 $\mu \mathrm{g})$ and their volumes were adjusted to $100 \mu \mathrm{l}$ with methanol. $5 \mathrm{~mL}$ of $0.1 \mathrm{mM}$ methanolic solution of $\mathrm{DPPH}^{*}$ was added and allowed to stand for $20 \mathrm{~min}$. at $27{ }^{\circ} \mathrm{C}$. The absorbance of the Usnic acid and Usnic acid diacetate were measured at $517 \mathrm{~nm}$. The percentage of DPPH radical scavenging activity of the sample were calculated as follows:

$\%$ DPPH radical scavenging activity $=($ control OD - sample OD/control OD) X 100
The $50 \%$ inhibition $\left(\mathrm{IC}_{50}\right)$ of Usnic acid and Usnic acid diacetate under the DPPH radical scavenging assay condition was calculated from the graph inhibition concentration against sample concentration. The experiment was performed in triplicates.

\subsection{Hydroxyl Radical Scavenging Activity}

The Hydroxyl radical scavenging activity of Usnic acid and Usnic acid diacetate were measured in reference with Klein et al. (1991)[5]. The Usnic acid and Usnic acid diacetate were taken at different concentrations $(100-500 \mu \mathrm{g}) 1 \mathrm{~mL}$ of iron-EDTA solution $(0.3 \%$ Ferrous ammonium sulfate and $0.26 \%$ EDTA solution $(0.018 \%)$, and $1 \mathrm{~mL}$ of dimethyl sulfoxide $(0.85 \% \mathrm{~V} / \mathrm{V}$ in $0.1 \mathrm{M}$ phosphate buffer, $\mathrm{pH} 7.4)$ are added to it. Using $0.5 \mathrm{~mL}$ of ascorbic acid $(022 \%)$ the reaction was initiated and was kept incubated at $80-90{ }^{\circ} \mathrm{C}$ for $15 \mathrm{~min}$. in a water bath. Later $1 \mathrm{~mL}$ of ice-cold TCA $(175.5 \% \mathrm{~W} / \mathrm{V})$ was added in order to terminate the reaction, then $3 \mathrm{~mL}$ of Nash reagent $(75.0 \mathrm{~g}$ of ammonium acetate, $3 \mathrm{~mL}$ of glacial acetic acid, and $2 \mathrm{~mL}$ of acetyl acetone were mixed and raised to $1 \mathrm{~L}$ with distilled water) was added and Kept at room temperature for about $15 \mathrm{~min}$. The colour intensity was measured spectroscopically at 412nm against the reagent blank. The \% hydroxyl scavenging activity was calculated as follows:

$\%$ Hydroxyl scavenging activity $=($ control OD - sample OD/control OD) X 100

The $50 \%\left(\mathrm{IC}_{50}\right)$ of Usnic acid and Usnic acid diacetate under the hydroxyl radical scavenging assay was calculated from the graph of inhibition percentage against sample concentration. The experiment was performed in triplicates.

\subsection{Superoxide Radical Scavenging Activity}

Superoxide radicals were formed by Beauchamp and Fridovich (1971)[6]. In this assay, the capacity of Usnic acid and Usnic acid diacetate can able to inhibit farmazan formation by scavenging the superoxide radicals generated in riboflavin-light-NBT system was measured. For this reaction a mixture of $50 \mathrm{mM}$ of Sodium phosphate buffer (pH 7.6), 20mg of riboflavin, $12 \mathrm{mM}$ of EDTA, $0.1 \mathrm{mg}$ NBT and Usnic acid and Usnic acid diacetate at different concentrations $(100-500 \mu \mathrm{g})$ were taken in $3 \mathrm{~mL}$. The reaction was started upon illumination of the reaction mixture with sample for 90 seconds. The absorbance were measured immediately at $590 \mathrm{~nm}$ after illumination. The entire reaction assembly were enclosed in a box lined with aluminium foil. The reaction mixture without the sample kept in dark served as blank. The percentage inhibition of superoxide anion generation was calculated as follows: $\%$ Superoxide radical scavenging activity $=($ control OD sample OD/control OD) X 100

The $50 \%$ inhibition $\left(\mathrm{IC}_{50}\right)$ of Usnic acid and Usnic acid diacetate under Superoxide radical scavenging assay condition was calculated from the graph of inhibition percentage against sample concentration. The experiment was performed in triplicates. 


\subsection{Ferric Reducing Antioxidant Power (FRAP)}

\section{Assay}

The FRAP assay was used to estimate the reducing capacity of the Usnic acid and Usnic acid diacetate, by Benzie and Strain, 1996[7]. The FRAP reagent contained $2.5 \mathrm{~mL}$ of a $10 \mathrm{mM}$ TPTZ solution in $40 \mathrm{mM} \mathrm{HCl}, 2.5 \mathrm{~mL}$ of $20 \mathrm{mM}$ $\mathrm{FeCl}_{3} \cdot 6 \mathrm{H}_{2} \mathrm{O}$ and $25 \mathrm{~mL}$ of $300 \mathrm{mM}$ acetate buffer ( $\left.\mathrm{pH} 3.6\right)$. It was freashly prepared and warmed at $37 \circ \mathrm{C}$. $900 \mu \mathrm{l}$ FRAP reagent was mixed with $90 \mu \mathrm{l}$ water and $10 \mu \mathrm{l}$ of the sample. The reaction mixture was incubated at $37{ }^{\circ} \mathrm{C}$ for 30 minutes and the absorbance was measured at $593 \mathrm{~nm}$. The experiment was performed in triplicates.

\subsection{Metal Chelating Activity}

The Chelation of Ferrous ions by Usnic acid and Usnic acid diacetate were estimated by Dinis et al. (1994)[8]. 50 $\mu$ l of $1 \mathrm{mM} \mathrm{FeCl} 2$ was mixed with $1 \mathrm{~mL}$ of the sample $(250 \mu \mathrm{g})$. $0.2 \mathrm{~mL}$ of $5 \mathrm{mM}$ ferrozine solution was added to initiate the recation. The mixture was shaken vigorously and kept at room temperature for $10 \mathrm{~min}$. The absorbance of the solution was measured at $562 \mathrm{~nm}$. The analysis was performed in triplicate and the results were expressed as EDTA equivalent. The experiment was performed in triplicates.

\subsection{Phosphomolybdenum Reduction assay}

The antioxidant activity of the Usnic acid and Usnic acid diacetate were evaluated by the phosphomolybdenum in reference with Prieto et al. (1999)[9]. In a 4mL vial, $1 \mathrm{~mL}$ regent solution $(0.6 \mathrm{M}$ sulphuric acid, $28 \mathrm{mM}$ sodium phosphate and $4 \mathrm{mM}$ ammonium molybdate) and an aliquiot of $0.1 \mathrm{~mL}$ of sample were taken. The vials were capped and incubated in a water bath at $95^{\circ} \mathrm{C}$ for 90 minutes. After cooling them to room temperature, the absorbance of the mixture were measured at $765 \mathrm{~nm}$ against a blank. The results were expressed as milligrams of ascorbic acid equivalents per gram sample. The experiment was performed in triplicates.

\subsection{Lipid Peroxidation Inhibiting Activity}

The lipid peroxidation inhibition ability of the Usnic acid and Usnic acid diacetate were carried out using a procedure of Ohkawa et al. (1979)[10]. Goat lliver was washed thoroughly in cold phosphate buffer saline $(\mathrm{pH} 7.4)$ and homogenized to give a $10 \%$ homogenate. The homogenate was filtered and centrifuged at $10000 \mathrm{rpm}$ for about $10 \mathrm{~min}$. and the supernatant used to carry out the assay. To the $0.5 \mathrm{~mL}$ of $10 \%$ homogenate, $0.5 \mathrm{~mL}$ of the sample $(50-$ $250 \mu \mathrm{g}$ ) was added followed by the addition of $0.05 \mathrm{~mL}$ of $0.07 \mathrm{M}$ ferrous sulphate and the mixture was incubated at room temperature for $30 \mathrm{~min}$. Then add $1.5 \mathrm{~mL}$ of $20 \%$ acetic acid (pH 3.5) and $1.5 \mathrm{~mL}$ of $0.8 \%$ TCA (in 1\% SDS) to the incubated solution. The tubes were incubated at $100{ }^{\circ} \mathrm{C}$ for $1 \mathrm{hr}$ and cooled to room temperature. To this $5 \mathrm{~mL}$ of butanol was added and centrifuged at $3000 \mathrm{rpm}$ for $10 \mathrm{~min}$. The absorbance for the upper layer was measured at $532 \mathrm{~nm}$. The percentage inhibition was calculated as follows:
$\%$ Lipid peroxidation inhibition $=($ control OD - Sample OD/control OD) X 100

The $50 \%$ inhibition $\left(\mathrm{IC}_{50}\right)$ of Usnic acid and Usnic acid diacetate under Lipid peroxidation assay condition was calculated from the graph of inhibition percentage against sample concentration.

\section{STATISTICAL ANALYSIS}

All assays were carried out in triplicates and result are expressed as mean \pm SD. Data were analyzed in Microsoft EXCEL-2010 by taking triplicates and thus mean and Standard Deviation (SD) obtained.

\section{RESULTS AND DISCUSSION}

Antioxidants can offer resistance against oxidative stress by scavenging the free radicals, inhibiting the lipid peroxidation, thus it provides prevention from many other diseases. In our present study, the antioxidant activity of the two test samples 1.Usnic acid and Usnic acid diacetate were analyzed.

\subsection{DPPH Free Radical Scavenging Activity}

1,1-Diphenyl-2-picrylhydrazl(DPPH), is one of the stable organic free radical which can facilitate the free radical scavenging assay of bioactive phyto-compounds. The DPPH free radical scavenging activity of the two test compounds Usnic acid and Usnic acid diacetate were determined at different concentration $(100 \mu 1,200 \mu 1,300 \mu 1$, $400 \mu \mathrm{l}$ and $500 \mu \mathrm{l})$. The $\mathrm{IC}_{50}$ values of the test compounds were also determined. The results were given in the Table: 1 . The dose dependent activity of the two test compounds and the standard were expressed in Chart: 1 and Chart: 2. From the results, it has been found that both the test compounds shows higher \% DPPH free radical scavenging activity as the concentration increases and also the Diacetate derivative of Usnic acid shows better scavenging activity than Usnic acid. Eventhough the two test compounds shows lesser activity as that of the standard tannic acid. 


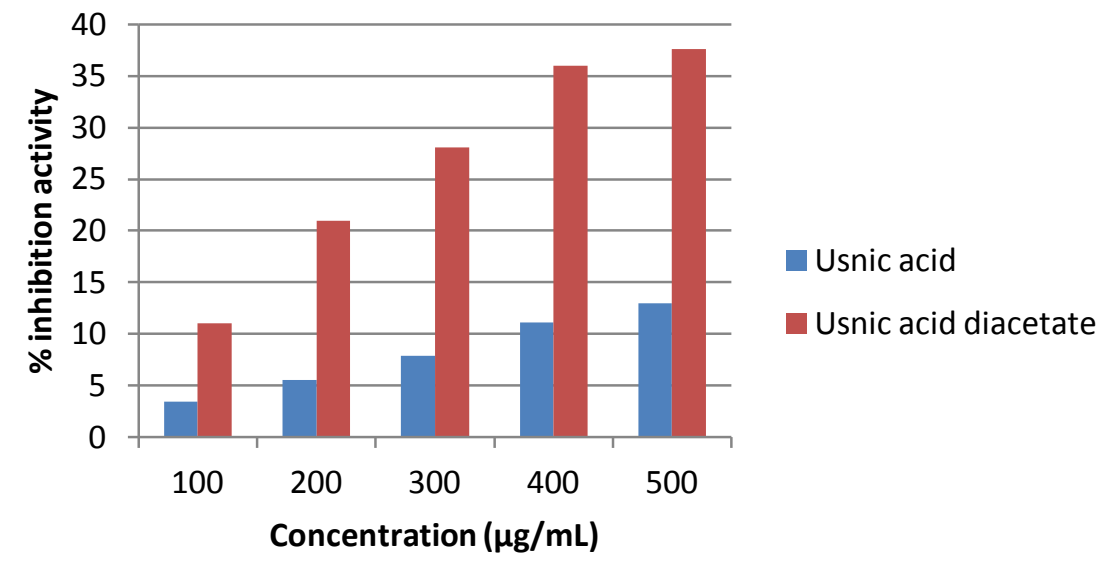

Chart: 1-DPPH Free Radical Scavenging Activity of Usnic acid and Usnic acid diacetate

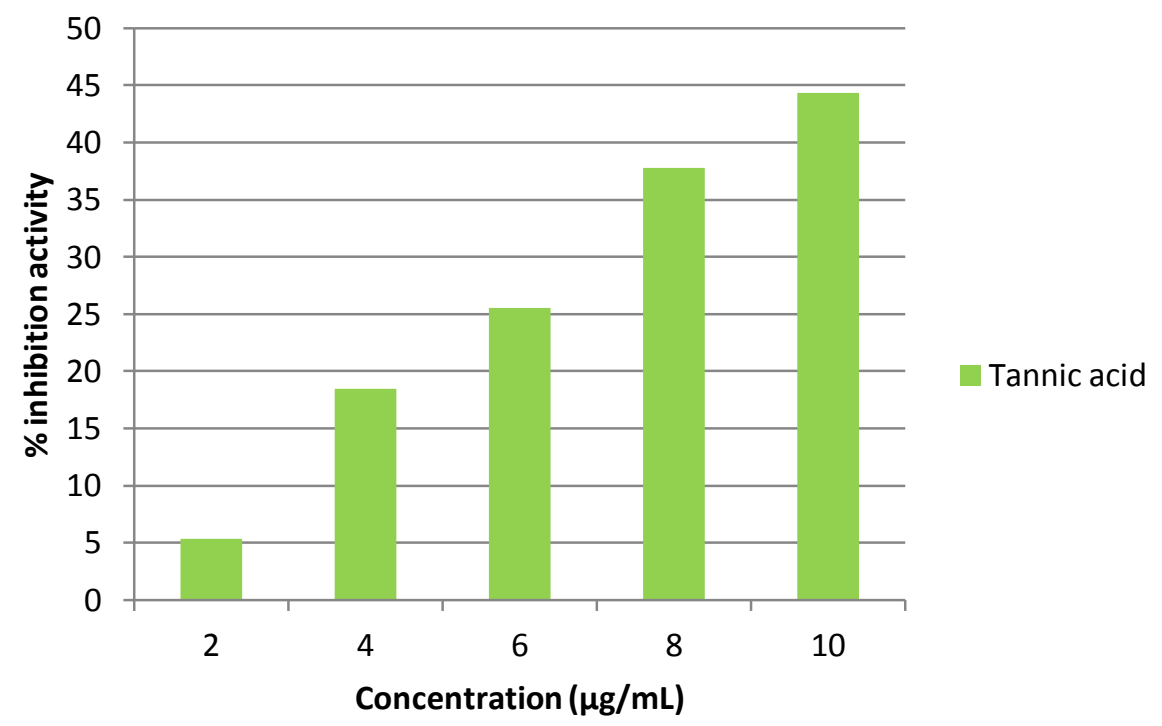

Chart: 2-DPPH Free Radical Scavenging activity of Standard Tannic acid

Table: 1-DPPH Free Radical Scavenging Assay

\begin{tabular}{|l|l|l|l|}
\hline $\begin{array}{l}\text { Test } \\
\text { compoun } \\
\mathbf{d}\end{array}$ & $\begin{array}{l}\text { Concentratio } \\
\mathbf{n} \\
\mathbf{( \mu g})\end{array}$ & \% Activity & $\mathbf{I C}_{\mathbf{5 0}}(\boldsymbol{\mu g} / \mathbf{m l})$ \\
\hline & & & \\
Usnic acid & 100 & $3.43 \pm 0.26$ & \\
& 200 & $5.56 \pm 0.50$ & \\
& 300 & $7.92 \pm 0.15$ & $691.36 \pm 31.10$ \\
& 400 & $11.09 \pm 0.71$ & \\
& 500 & $12.99 \pm 0.45$ & \\
\hline & 100 & $11.02 \pm 1.08$ & \\
Usnic acid & 200 & $20.94 \pm 0.94$ & \\
diacetate & 300 & $28.07 \pm 2.76$ & $215 \pm 14.12$ \\
& 400 & $35.98 \pm 1.92$ & \\
\hline & 500 & $37.62 \pm 2.33$ & \\
Tannic & 2 & $5.31 \pm 0.54$ & \\
acid & 6 & $18.45 \pm 0.17$ & \\
& 8 & $25.50 \pm 0.38$ & $4.31 \pm 0.02$ \\
& 10 & $37.78 \pm 0.38$ & \\
\hline
\end{tabular}




\subsection{Hydroxyl Radical Scavenging Activity}

Hydroxyl radical was formed from the various biological mechanism can damage protein, facilitates lipid peroxidation, affects the DNA sequences. The Hydroxyl radical scavenging activity of the two test compounds Usnic acid and Usnic acid diacetate were determined at different concentration $(100 \mu \mathrm{l}, 200 \mu \mathrm{l}, 300 \mu \mathrm{l}, 400 \mu \mathrm{l}$ and $500 \mu \mathrm{l})$. The $\mathrm{IC}_{50}$ values of the test compounds were also determined. The results were given in the Table: 2 . The dose dependent activity of the two test compounds and the standard were expressed in Chart: 3 and Chart: 4. From the result, it has been revealed that the \% inhibition activity of two test compounds shows higher activity as increase in their concentration and also the usnic acid has better efficiency than Usnic acid diacetate in scavenging the Hydroxyl radicals. But, the two test compounds shows only lesser activity when compared to the standard Tannic acid.

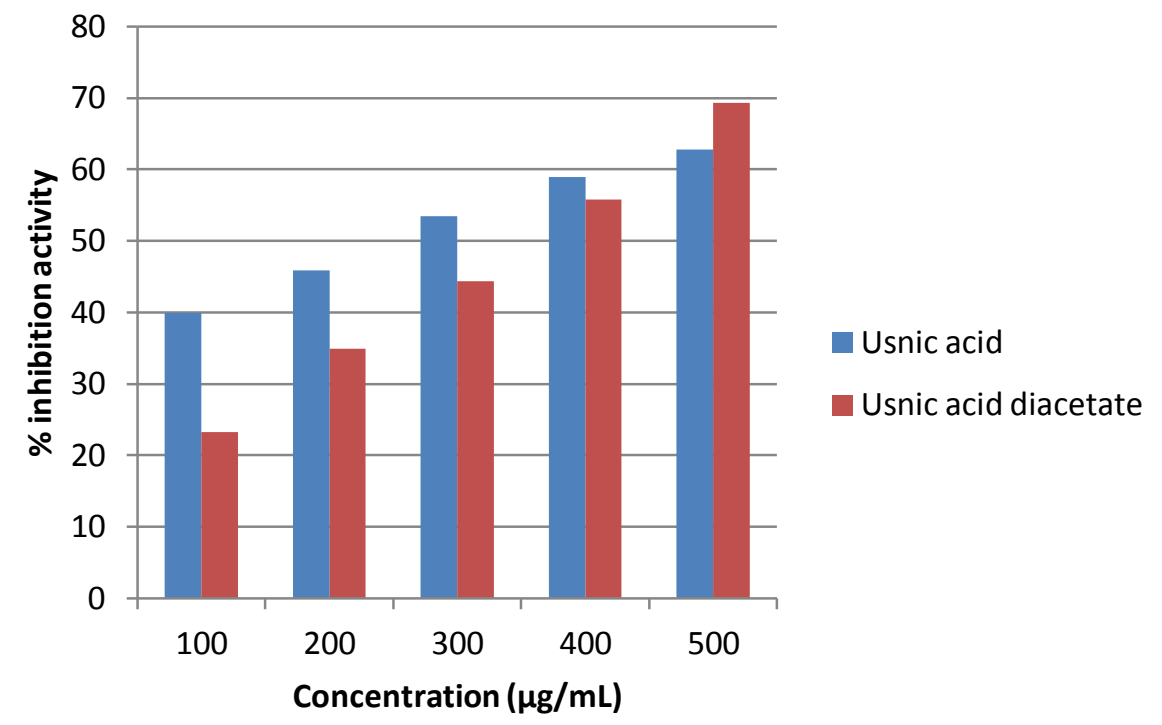

Chart: 3-Hydroxyl Radical Scavenging Activity of the Usnic acid and Usnic acid diacetate

\section{Tannic acid}

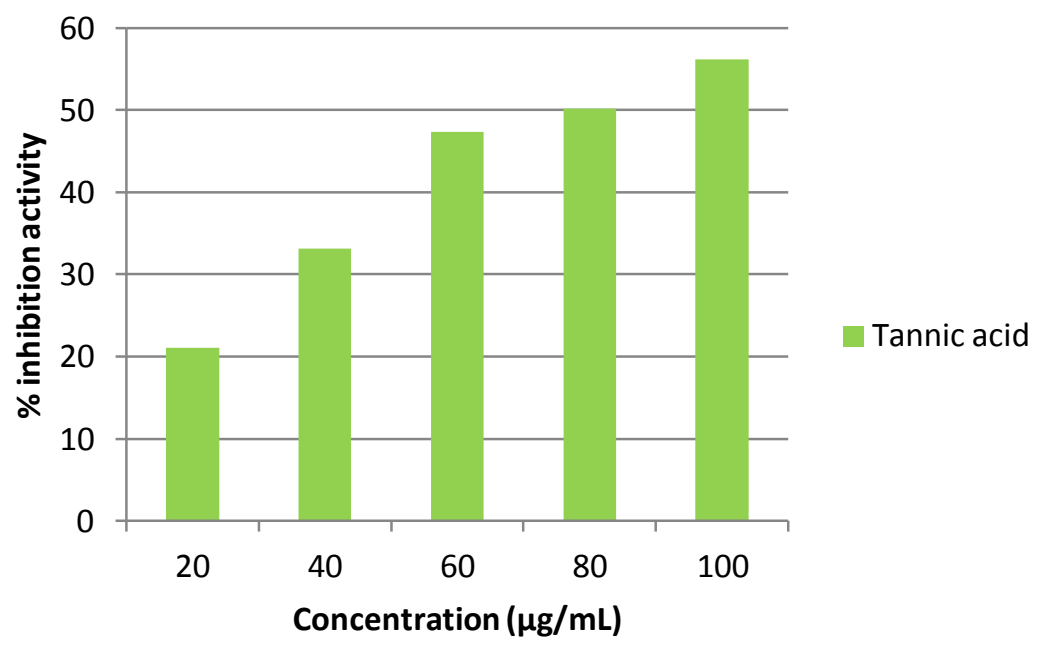

Chart: 4-Hydroxyl Radical Scavenging Activity of the standard Tannic acid 
Table: 2-Hydroxyl Radical Scavenging Assay

\begin{tabular}{|l|l|l|l|}
\hline $\begin{array}{l}\text { Test } \\
\text { compound }\end{array}$ & Concentration $(\boldsymbol{\mu g})$ & $\begin{array}{l}\boldsymbol{\%} \\
\text { Activity }\end{array}$ & $\begin{array}{l}\mathbf{I C}_{\mathbf{5 0}} \\
(\boldsymbol{\mu g} / \mathbf{m l})\end{array}$ \\
\hline & 100 & $39.95 \pm 0.52$ & \\
& 200 & $45.87 \pm 0.46$ & \\
Usnic acid & 300 & $53.44 \pm 0.47$ & $119.10 \pm 0.45$ \\
& 400 & $58.97 \pm 0.47$ & \\
& 500 & $62.73 \pm 0.54$ & \\
\hline & 100 & $23.22 \pm 0.57$ & \\
Usnic acid & 200 & $34.89 \pm 0.52$ & \\
diacetate & 400 & $44.31 \pm 0.20$ & $125.98 \pm 1.01$ \\
& 500 & $55.77 \pm 0.79$ & \\
\hline & 20 & $69.30 \pm 0.49$ & \\
Tannic & 60 & $21.06 \pm 0.52$ & \\
acid & 80 & $33.18 \pm 0.00$ & \\
& 100 & $47.35 \pm 0.52$ & $21.51 \pm 0.19$ \\
\hline
\end{tabular}

\subsection{Superoxide Dismutase Activity}

The superoxide anion radical is a most potent reactive oxygen species which causes harmful effects on the biological defence mechanism. The Superoxide radical scavenging activity of the two test compounds Usnic acid and Usnic acid diacetate were determined at different concentration $(100 \mu \mathrm{l}, 200 \mu \mathrm{l}, 300 \mu \mathrm{l}, 400 \mu \mathrm{l}$ and $500 \mu \mathrm{l})$. The $\mathrm{IC}_{50}$ values of the test compounds were also determined. The results were given in the Table: 3 . The dose dependent activity of the two test compounds and the standard were expressed in Chart: 5 and Chart: 6. From the result, it was found that Usnic acid shows higher \% inhibition activity as the concentration increases. But the Usnic acid diacetate shows very lesser activity in scavenging the superoxide radicals. Also in comparison with the standard Tannic acid, both the test compounds shows lesser activity.

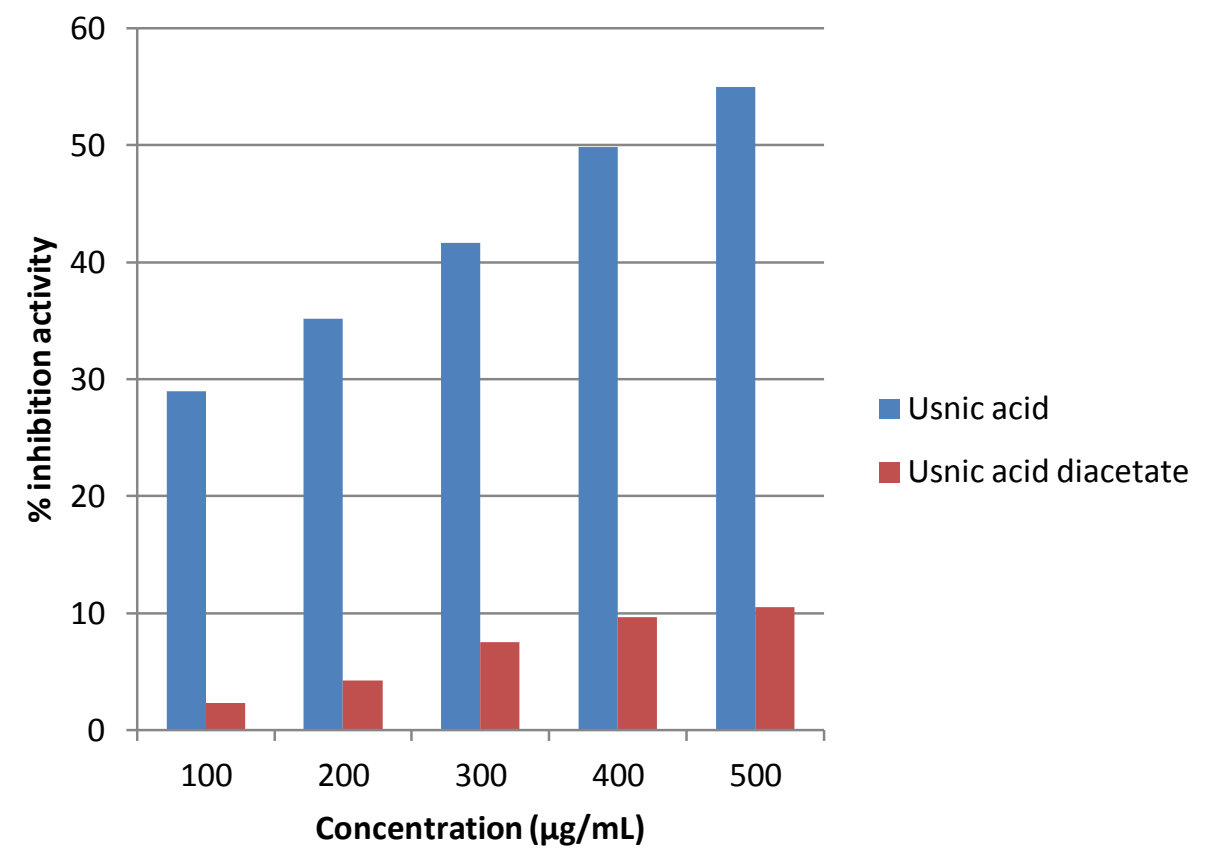

Chart: 5-Superoxide Radical Scavenging Activity of the Usnic acid and Usnic acid diacetate 


\section{Tannic acid}

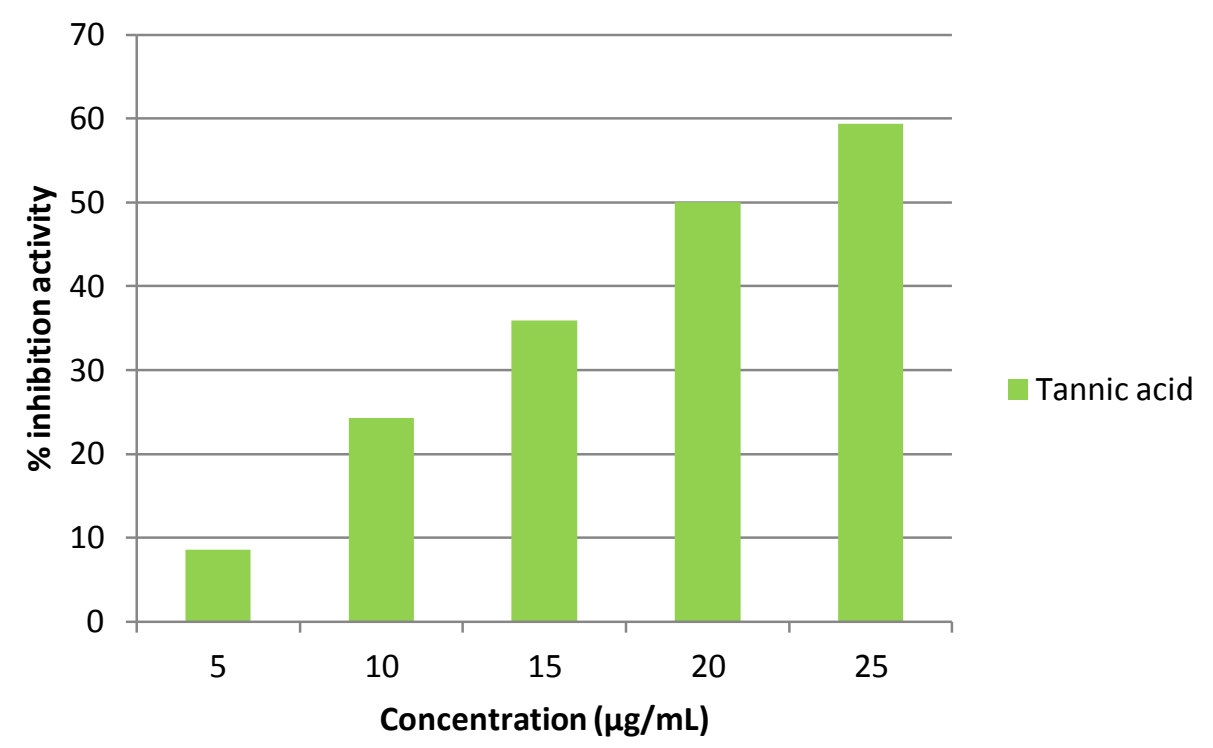

Chart: 6-Superoxide Radical Scavenging Activity of the standard Tannic acid

Table: 3-Superoxide Radical Scavenging Activity

\begin{tabular}{|l|l|l|l|}
\hline $\begin{array}{l}\text { Test } \\
\text { compound }\end{array}$ & Concentration$(\boldsymbol{\mu g})$ & $\boldsymbol{\%}$ Activity & $\begin{array}{l}\mathbf{I C}_{\mathbf{5 0}} \\
(\boldsymbol{\mu g} / \mathbf{m l})\end{array}$ \\
\hline & 50 & $6.21 \pm 0.81$ & \\
Usnic acid & 100 & $9.75 \pm 1.11$ & \\
& 150 & $17.02 \pm 1.06$ & $44.57 \pm 1.06$ \\
& 200 & $25.18 \pm 0.18$ & \\
& 250 & $32.45 \pm 0.53$ & \\
\hline & 50 & $7.45 \pm 0.92$ & \\
Usnic acid & 100 & $12.41 \pm 1.34$ & \\
diacetate & 200 & $18.26 \pm 0.81$ & $46.58 \pm 1.03$ \\
& 150 & $23.23 \pm 1.11$ & \\
\hline & 50 & $29.26 \pm 1.06$ & \\
Tannic acid & 100 & $46.77 \pm 0.78$ & \\
& 150 & $57.14 \pm 1.35$ & \\
& 200 & $71.43 \pm 2.23$ & $13.37 \pm 0.21$ \\
& 250 & $87.41 \pm 2.06$ & \\
\hline
\end{tabular}

\subsection{Lipid Peroxidation Inhibiting Activity}

Lipid peroxidation was toxicological process, responsible for the excessive production of variety of reactive oxygen species, which in turn causes modification of lipoprotein, DNA sequences, proteins. The Lipid peroxidation inhibiting activity of the two test compounds Usnic acid and Usnic acid diacetate were determined at different concentration $(100 \mu 1,200 \mu 1,300 \mu l, 400 \mu l$ and $500 \mathrm{\mu l}$ ). The $\mathrm{IC}_{50}$ values of the test compounds were also determined. The results were given in the Table: 4 . The dose dependent activity of the two test compounds and the standard were expressed in Chart: 7. From the result, it has been identified that the lipid peroxidation inhibiting activity of the two test compounds have shown significant activity at higher concentration but shown lesser activity than the standard Tannic acid. 


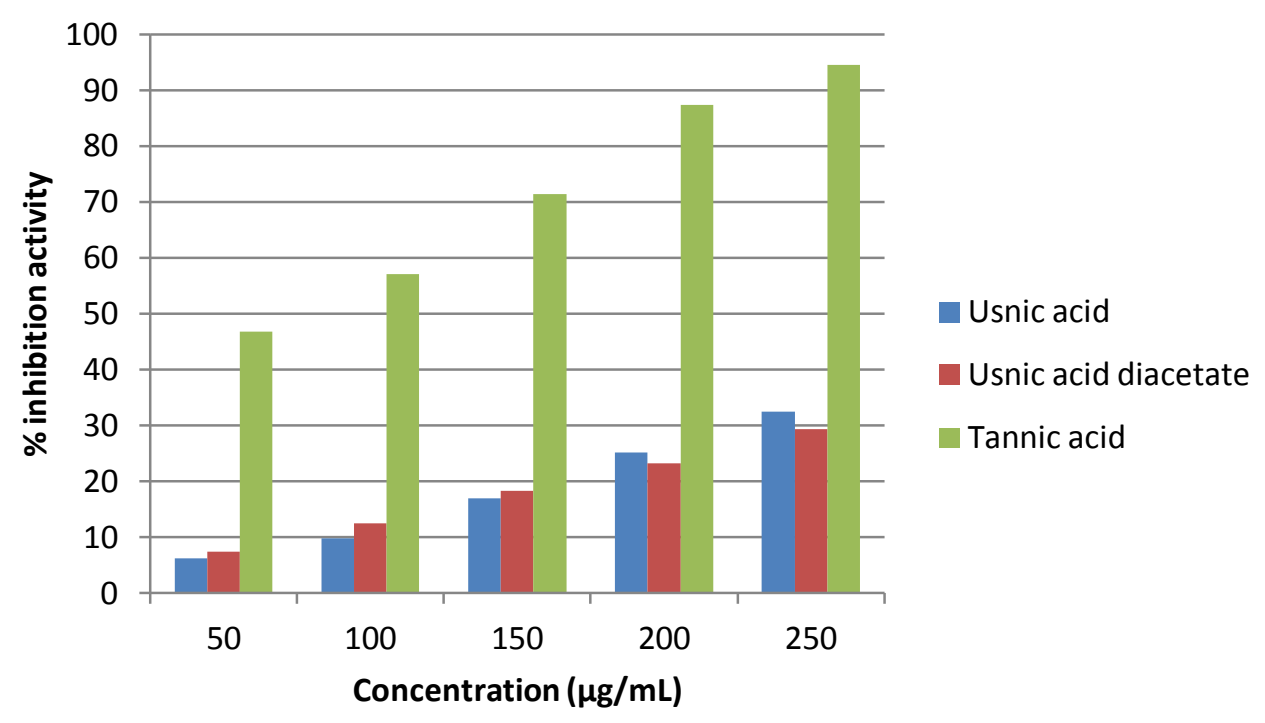

Chart: 7-Lipid Peroxidation Inhibiting Activity of Usnic acid, Usnic acid diacetate and Tannic acid

Table: 4-Lipid Peroxidation Inhibiting Activity

\begin{tabular}{|l|l|l|l|}
\hline $\begin{array}{l}\text { Test } \\
\text { compound }\end{array}$ & $\begin{array}{l}\text { Concentration } \\
(\boldsymbol{\mu g})\end{array}$ & $\begin{array}{l}\boldsymbol{\%} \\
\text { Activity }\end{array}$ & $\mathbf{I C}_{\mathbf{5 0}}(\boldsymbol{\mu g} / \mathbf{m l})$ \\
\hline & 100 & $28.94 \pm 0.46$ & \\
Usnic acid & 200 & $35.13 \pm 0.73$ & \\
& 300 & $41.63 \pm 0.73$ & $121.46 \pm 0.56$ \\
& 400 & $49.85 \pm 0.90$ & \\
& 500 & $54.94 \pm 0.66$ & \\
& 100 & $2.33 \pm 0.33$ & \\
Usnic acid & 200 & $4.26 \pm 0.62$ & \\
diacetate & 300 & $7.55 \pm 0.65$ & $689.17 \pm 17.55$ \\
& 500 & $9.66 \pm 0.20$ & \\
\hline & 5 & $10.50 \pm 0.20$ & \\
Tannic & 10 & $8.54 \pm 0.36$ & \\
acid & 15 & $24.24 \pm 0.23$ & \\
& 20 & $35.90 \pm 0.23$ & $6.40 \pm 0.05$ \\
\hline
\end{tabular}

Table: $5-\mathrm{IC}_{50}$ value of the test compounds and the standard

\begin{tabular}{|l|l|l|l|}
\hline $\begin{array}{l}\text { Method of } \\
\text { antioxidant } \\
\text { assay }\end{array}$ & $\begin{array}{l}\text { Usnic acid } \\
\mathbf{I C}_{\mathbf{5 0}} \text { Value } \\
(\boldsymbol{\mu g} / \mathbf{m L})\end{array}$ & $\begin{array}{l}\text { Usnic acid } \\
\text { diacetate } \\
\mathbf{I C}_{\mathbf{5 0}} \text { Value } \\
(\boldsymbol{\mu g} / \mathbf{m L})\end{array}$ & $\begin{array}{l}\text { Standard } \\
\text { Tannic acid } \\
\mathbf{I}_{\mathbf{5 0}} \text { Value } \\
(\boldsymbol{\mu g} / \mathbf{m L})\end{array}$ \\
\hline $\begin{array}{l}\text { DPPH } \\
\text { Radical } \\
\text { Scavenging }\end{array}$ & $691.36 \pm 31.10$ & $215.36 \pm 14.12$ & $4.31 \pm 0.02$ \\
\hline $\begin{array}{l}\text { Superoxide } \\
\text { Dismutase } \\
\text { activity }\end{array}$ & $121.46 \pm 0.56$ & $689.17 \pm 17.55$ & $6.40 \pm 0.05$ \\
\hline $\begin{array}{l}\text { Hydroxyl } \\
\text { radical } \\
\text { Scavenging }\end{array}$ & $119.10 \pm 0.45$ & $125.98 \pm 1.01$ & $21.51 \pm 0.91$ \\
\hline $\begin{array}{l}\text { Lipid } \\
\text { Peroxidation }\end{array}$ & $44.57 \pm 1.06$ & $46.58 \pm 1.03$ & $13.37 \pm 0.21$ \\
\hline
\end{tabular}




\subsection{Phosphomolydenum Assay}

The Phosphomolybdenum assay of the two test compounds and standard were given in the Table: 6. The total antioxidant activities of the test compounds and the standard were shown in the Chart: 8. From the Result, it has been established that the Usnic acid diacetate shows higher total antioxidant activity than the standard Tannic acid. But Usnic acid shows comparatively lesser total antioxidant activity than Usnic acid and Tannic acid.

Table:6-Phosphomolybdenum assay

\begin{tabular}{|l|l|}
\hline Sample & $\begin{array}{l}\text { Phosphomolydenum } \\
\text { (mg ascorbic acid eq./g } \\
\text { sample) }\end{array}$ \\
\hline Usnic acid & $59.36 \pm 3.96$ \\
Tannic acid diacetate & $383.38 \pm 1.92$ \\
& $187.21 \pm 80.27$ \\
\hline
\end{tabular}

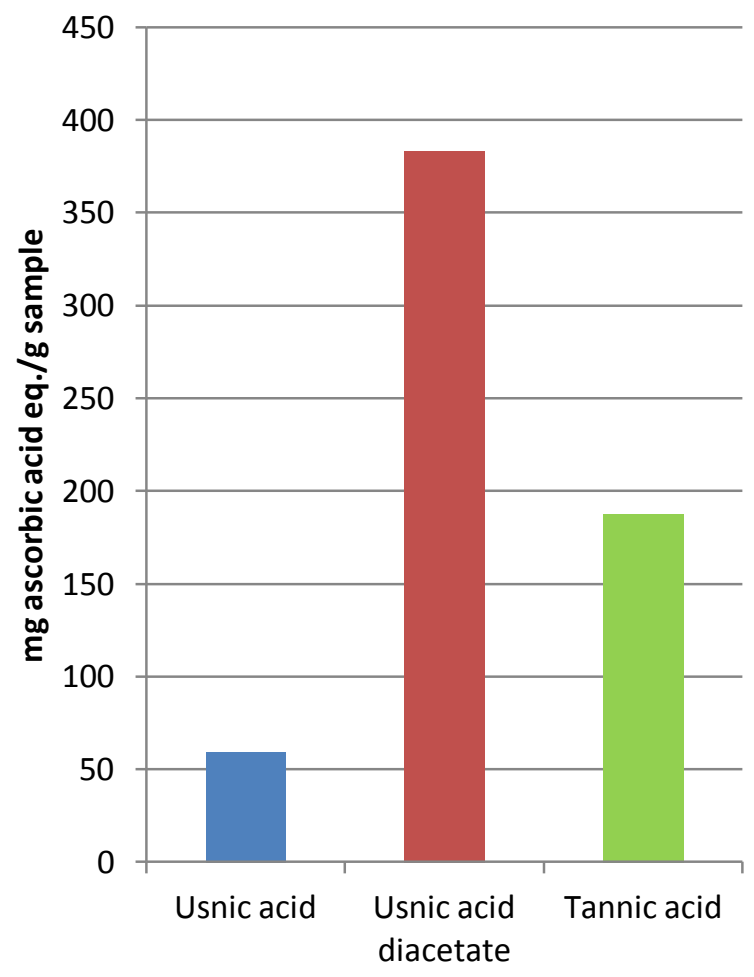

Usnic acid

- Usnic acid diacetate

Tannic acid

Chart: 8-Phophomolybdenum Assay of Usnic acid, Usnic acid diacetate and Tannic acid

\subsection{FRAP Assay}

The FRAP assay of the two test compounds and standard were given in the Table: 7. The Ferric reducing antioxidant activities of the test compounds and the standard were shown in the Chart: 9. From the results, Usnic acid diacetate shows higher activity than Usnic acid. But both the test compounds are less active than Tannic acid in reducing Ferric ions. 


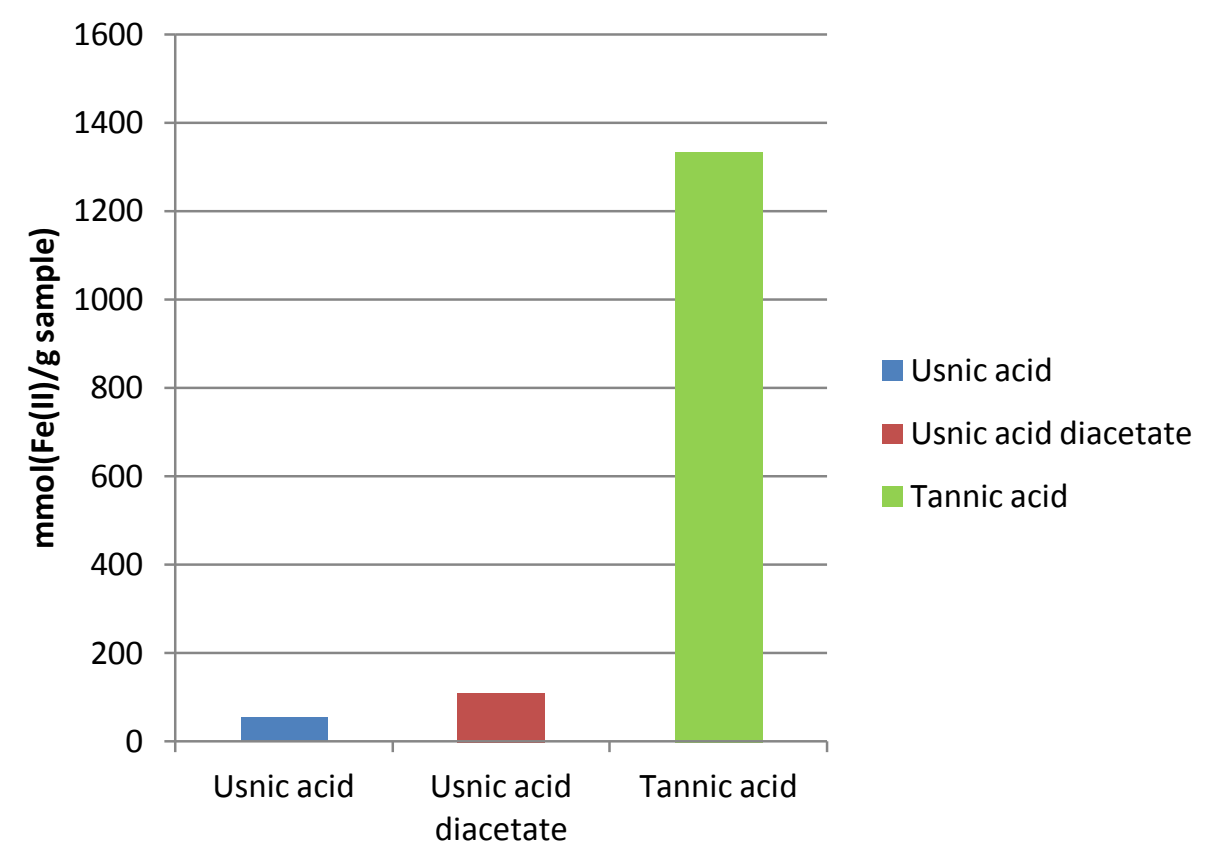

Chart: 9-FRAP assay of Usnic acid, Usnic acid diacetate and Tannic acid

Table: 7-FRAP Assay

\begin{tabular}{|l|l|}
\hline Sample & $\begin{array}{l}\text { FRAP } \\
\text { sample } \quad \mathbf{m m o l}(\mathbf{F e}(\mathbf{I I}) / g)\end{array}$ \\
Usnic acid & $54.89 \pm 5.07$ \\
Tannic acid diacetate & $108.42 \pm 6.94$ \\
& $1335.00 \pm 160.09$ \\
\hline
\end{tabular}

\subsection{Metal Chelating Activity}

$\mathrm{Fe}^{2+}$ ions have the tendency to trigger free radical generation to some extent, it would be beneficial to chelate such $\mathrm{Fe}^{2+}$ ions. The Metal chelating activity of the two test compounds and standard were given in the Table: 8 . The metal chelating activities of the test compounds and the standard were shown in the Chart: 10. From the results, it has been found that both Usnic acid and Usnic acid diacetate shows nearly similar metal chelating activity and also very less active than the standard Tannic acid.

Table: 8-Metal Chelating Activity

\begin{tabular}{|l|l|}
\hline Sample & $\begin{array}{l}\text { Metal chelating activity } \\
\text { (mg EDTA eq./g sample) }\end{array}$ \\
\hline Usnic acid & $12.35 \pm 0.08$ \\
Usnic acid diacetate & $10.46 \pm 0.13$ \\
Tannic acid & $126.85 \pm 4.04$ \\
\hline
\end{tabular}




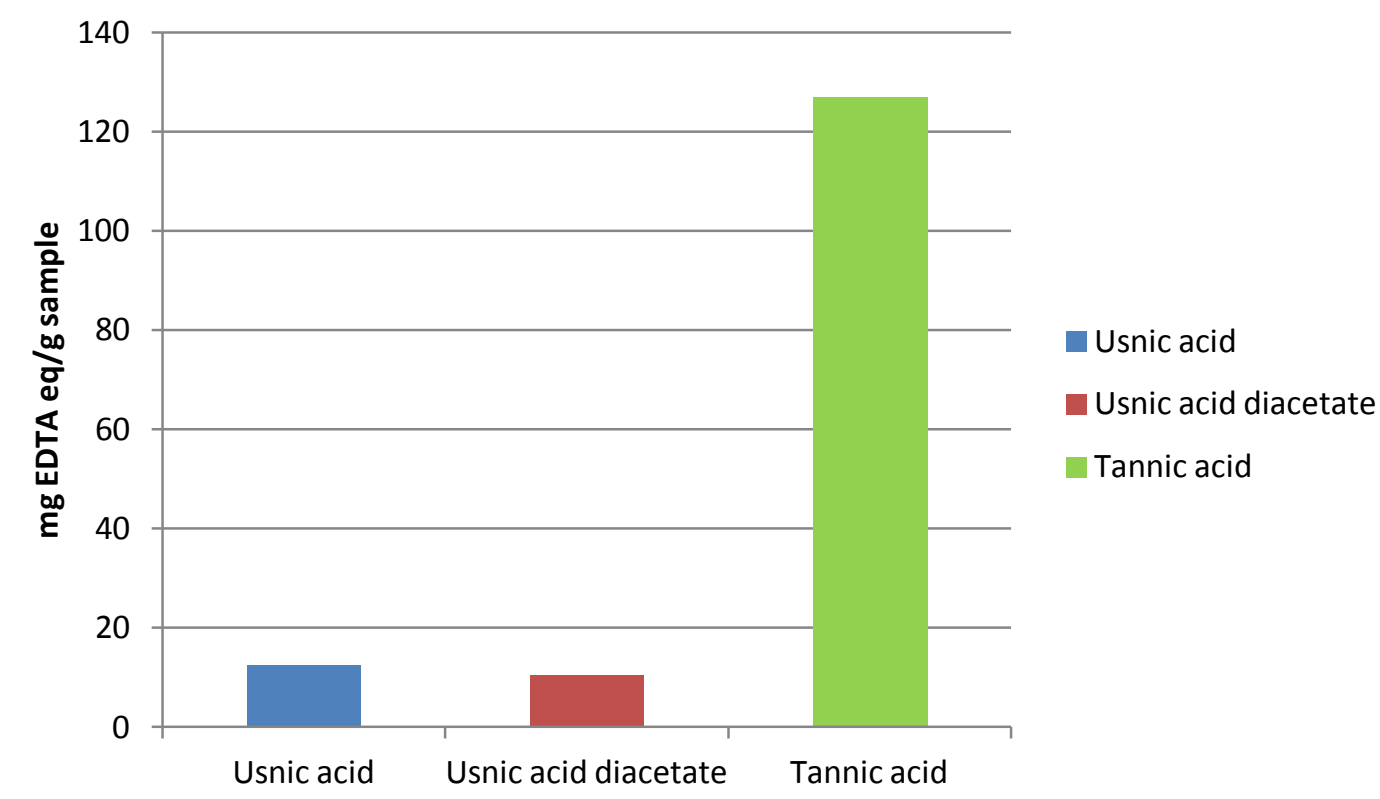

Chart: 10-Metal Chelating Activity of Usnic acid, Usnic acid diacetate and Tannic acid

\section{CONCLUSION}

In the present study, it is concluded that the lichen secondary metabolite Usnic acid and its derivative Usnic acid diacetate have possesses efficient antioxidant properties and are reported that they are dose dependent. But among the two test compounds Usnic acid gives lower $\mathrm{IC}_{50}$ value for Hydroxyl scavenging activity, Superoxide dismutase scavenging activity and shows better activity than Usnic acid diacetate, for DPPH radical scavenging while Usnic acid diacetate gives lower $\mathrm{IC}_{50}$ value and possesses better activity than Usnic acid for lipid peroxidation inhibiting activity both the test compounds shows lesser activity. It was known that lower the $\mathrm{IC}_{50}$ value higher the inhibition activity. Also Usnic acid diacetate possesses higher total antioxidant activity via Phosphomolydenum assay than Usnic acid and Tannic acid. In FRAP assay Usnic acid dicetate shows higher activity than Usnic acid. On the other hand metal chelating activity of both Usnic acid and Usnic acid diacetate was found to be very less. From the result it was found that both the two test compounds shows lesser activity than the standard tannic acid for DPPH, Hydroxyl scavenging activity, Superoxide dismutase scavenging activity, lipid peroxidation inhibiting activity, Metal chelating activity and FRAP asaay. Since, our test compounds are obtained naturally and are free from side effects. Thus, both the test compounds can found to be a good primary antioxidant.

\section{REFERENCE}

[1] Vivek M.N, Yashoda Kambar, Manasa M, Prashith Kekuda T.R, Vinayaka K.S. "Radical scavenging and antibacterial activity of three Parmotrema species from Western Ghats of Karnataka, India”. Journal of Applied Pharmaceutical Science; 2014; 4(3); 86-91.
[2] Binod Chandra Sharma, Sujata Kalikotay. "Screening of antioxidant activity of lichens Parmotrema reticulatum and Usnea sp. From Darjeeling hills, India". Journal of Pharmacy. 2012; 2(6); 54-60.

[3] Ramesh C.K, Raghu K.L, Jamuna K.S, Govinden Soulange Joyce, Ranghoo Sanmukhiya Vijayanti Mala, Vijay Avin B.R. "Comparative evaluation of antioxidant property in methanol extracts of some common vegetables of India”. Annal of Biological Research; 2011, 2(2); 86-94.

[4] Blois MS. Antioxidant determination by the use of stable free radical. Nature. 1958; 26: 1199-1200.

[5] Klein SM, Cohen G and Cederbaum AI. Production of formaldehyde during metabolism of dimethyl sulphoxide by hydroxyl radical scavenging system. Biochem. 1991; 20: 6006-6012

[6] Beauchamp C and Fridovich I. Superoxide dismutase: Improved assays and an assay applicable to acrylamide gels. Anal. Biochem. 1971; 44: 276-277.

[7] Benzie IF, Strain JJ. The ferric reducing ability of plasma (FRAP) as a measure of "Antioxidant power" The FRAP assay. Anal. Biochem. 1996; 239: 70-76.

[8] Dinis TCP, Maderia VMC and Almeidia MCM. Action of phenolic derivatives (acetoaminophen, salycilate and 5-aminosalycilate) as inhibitors of membrane lipid peroxidation and as peroxyl radical scavenger. Arch. Biochem. Biophys. 1994; 315: 161169.

[9] Preito P, Pineda $M$ and Aguilar $M$. Spectrophotometric quantitation of antioxidant capacity through the formation of a phosphomolybdenum complex: specific application to the determination of vitamin E. Anal. Biochem. 1999; 269: 337-341.

[10] Ohkawa, H., Ohishi, N., Yagi, K. Assay for lipid peroxides in animal tissues by thiobarbituric acid reaction. Anal. Biochem. 1979; 95: 351-358. 